\title{
Main Reasons against Unnatural Marriage and Its Wreckful Role in the Institution of Marriage and Family
}

\author{
Rasoul Rasolipour ${ }^{1}$, Mohammd Roshan ${ }^{1} \&$ Shapour Nikandam $^{2}$ \\ ${ }^{1} \mathrm{PhD}$, Faculty Member of Tehran Kharazmi University, Tehran, Iran \\ ${ }^{2} \mathrm{PhD}$ Student of Jurisprudence and Private Law, Faculty of Law, Tehran Kharazmi University, Tehran, Iran \\ Correspondence: Shapour Nikandam, PhD Student of Jurisprudence and Private Law, Faculty of Law, Tehran \\ Kharazmi University, Tehran, Iran. E-mail: shahpournikandam@gmail.com
}

\author{
Received: May 10, 2016 Accepted: June 3, 2016 Online Published: June 24, 2016 \\ doi:10.5539/jpl.v9n7p9 URL: http://dx.doi.org/10.5539/jpl.v9n7p9
}

\begin{abstract}
The role of marriage and family strengthening with regard to religious commandments and ethics is not concealed from people who follow the divine commands and basic teachings of the Holy books and prophets. However, nowadays in many western societies, the principles of natural marriage are violated. The new forms of marriage are called abnormal, unnatural, and unusual forms of marriage among individuals including the same or opposite sex. Unnatural marriage can't be classified as a natural and legal contract. Note that both natural and unnatural forms of marriage have their own principles. Therefore, the recent research aims at analyzing the main reasons against unnatural marriage using analytical and library methods with regard to the fact that unnatural marriage has threatened standard marriage and family foundation. In this research, we rely on verses of Quran. All the data have been gathered by experts in the field of family affairs especially those who witnessed homosexual marriage and observed both personal and social difficulties of homosexual individuals.
\end{abstract}

Keywords: marriage, morality, natural, religion, unnatural

\section{Introduction}

The fact that family is the smallest and the oldest social institution and the development and elevation of a society depends on a successful and prosperous family is not considered as a controversial approach. All the religions and savants have emphasized on it and admitted the mentioned approach. Note that Western societies resort to some concepts such as the equality of men and women influenced by feminism theory, democracy, religion and moral separation from all aspects of social position called secularism. Natural marriage was threatened in a serious manner and has put the family in danger of disintegration. As a result of the development of quasi matrimonial legal institutions such as civil partnership, cohabitation, and homosexual marriage, families have been diverted from their natural and intrinsic circuit. The whole regulations derived from natural marriage enact on unnatural marriage. It can be concluded that unnatural marriage hides the value of natural marriage which is considered as a principle followed by people all over the world. Considering the development of unnatural marriage, heterosexual forms of marriage lose their stability and turn into vulnerable contracts. As a result, children will be affected by these abnormal principles in a negative manner so it is necessary to identify the reasons presented against unnatural marriage based on verses of Quran and investigate their mal-functions in the institution of marriage. Consequently, we can increase our understanding about religious commandments and their importance in family foundation.

\subsection{God and His Opposition with Any Kind of Sexual Relation among People except in Marriage}

In Holy books including Gospel, any kind of sexual relationship between a man and a woman is forbidden except after marriage. According to God's commands, marriage is a contract between a man and a woman. In genesis journey it is stated: "so a man leaves his parents and starts his new life with his wife so they should be loyal toward each other when they are called husband and wife. Homosexuals have claimed that Jesus Christ never convicted homosexuality so it is possible to marry the same sex. However, the proponents of Jesus Christ believe that, this claim shows their ignorance and unawareness toward homosexuality. Also they proved that Jesus Christ has convicted scurrilous and immoral paintings so there is no doubt that he has convicted homosexuals as well (Rice et al., 1999). In Matthew book: "Christ fully condemned written- depicted absurd and 
pornographic images" (Ibid). The word "Porneia" can be defined as an immoral and corrupting sexual relationship. In many interpretations, abnormal sexual relationships are considered as inevitable sins. These acts are convicted in the ancient law: premarital sex, adultery; homosexuality, incest, and bestiality. Christ confirmed the contract as God's command and considering them, the Almighty God has created women only for men. For instance, God has created Eve for Adam so he has convicted any other form of marriage (homosexual marriage) for human beings. Even the Islamic religion emphasizes on heterosexual marriage and inhibited individuals from other forms of marriage. In Araf surah, verses 80 and 81 it has been stated: "We sent Lot to his tribe when he said that his people don't obey his commands and they only follow the wrong traditions of their ancestors". He also said: "You are a lavish group because you intermingle with men instead of women". Considering this fact, God has created women for men and men for women, male for female and female for male. Most of the verses of the Holy Quran have emphasized on this fact. According to Araf surah, "God is the one who created you from one body and created women to tranquil men". In verse 13 of Hojarat surah it is stated: "O Thou people, we have created you from one man and woman and we divided you to large and small sects to get to know each other. Definitely the most beloved one among you is the most abstinence one among you".

\subsection{Marriage of Two opposite Genders, Its Consistency and Adaptation with Innate System, Human Essence and Nature}

The marriage of a man with another man or a woman with another woman violates the principles of natural marriage because it is against normal marriage. So marriage on its opposite direction can cause different problems for the current and future generations. Regarding the fact that duality is the reason cause of evolution consequently absence of it may lead to defect and nonexistence. In one of legal experts' interpretations it is stated: "In the world, maleness and femaleness can be observed in every object with various shapes including negative and positive poles of atom and their continuance is in these manners and types (Roshan, 2013). Lauderdale presents a simple allegory in which he states that duality not only occurs among human beings but also it is common among vegetables and animals. He adds: "if you want to turn on a light, you can ask another person to do this, however, he cannot install the lamp at the place that he wants, but he needs to place it in the proper situation to achieve his goal. This electrical reaction is sometimes called maleness or femaleness. Until this connection key (called masculine) is not placed in its proper place (called feminine) and is not connected to a third phenomenon in a proper manner" (Kennedy, 2004). About homosexual marriage, we have to say that considering the point that at least half of human decent is masculine and half of it is feminine, when men marry together the role of women as mothers is neglected. Also when a woman marries to another woman, the role of men as fathers is neglected. Mat Daniele of the alliance for marriage institution remarks that homosexual families discriminate against parents because in such families, the role of parents is not defined. Male and female homosexual couples discriminate against mothers and fathers in a reciprocal manner. This institution adds "if you say that a gay couple can provide a healthy and calm environment as parents then you originate a deep negative statement about women. Also, you say that half of human generation doesn't affect child creation and reproduction phenomena. According to the fact that they have a unique role in rearing the next generation in a practical manner, this participation has been rejected by them. In other words, this is a humiliating and disgraceful statement for women because it means that a lesbian couple can give birth to a child. Your negative statement about men who are considered as the other half of human generation is that you see their presence unnecessary and it means that there is no need to men and they have no important role in families. These two ridiculous statements are wrong because children need both mother and father as two opposite genders" (Transcript for an interview with Mat Daniele of the alliance for marriage). The duality system in genesis and legislation world is described in Islamic texts in a beautiful and complete manner. In verse 7 of Shurah Surah, it is stated: "Did they see the ground in which we have put a good child for each couple". In Najm surah, verse 45, it is mentioned: "And so He has created masculine and feminine couples". Another example can be referred to as $36^{\text {th }}$ verse of Yasin surah in which the Almighty God says: "I have created all creatures on the ground as couples, the creatures that they even don not know". Al-Mizan has supported the wonderful statements of God. It says: "coupling matter is something different from creating human beings. It does not refer to any specific group including human beings, animals, or vegetables and He has created all creatures this way" (Tabatabaee, 1988). With regard to the fact that duality in genesis world and creation system is considered as an intrinsic and natural phenomenon, any kind of action or movement against it causes deficiency and decadence in men and women. Note that there is no exception. Any kind of relationship among men and women except innate and natural marriage has no results other than devastation and destruction of marriage institution.

\subsection{Natural and Innate Marriage and Its Adaptation with Historical and Cultural Records}

When we observe human millennial history, we can conclude that marriage and coupling were constantly 
concomitant with human beings. The natural form of marriage emphasizes on the heterosexual relationships of husbands and wives. Children should follow these principles and follow the normal form of marriage in the future. Polygamy which is permitted in Islam under specific circumstances has allowed marriage between only a man and a woman. As an efficient rule, marriage is usually between a man and a woman and a relationship other than this like homosexuality is seen as a perversion and abnormal phenomenon. A psychologist called Dr. Joseph Nicolosi has stated that, a classic and categorized study on 76 different cultures proved that the highest tendency among them is inclination and interest to opposite sex and they could not bear something other than this, this exception was never supported and no particular principle has been defined for it" (Finnis, 1994). By a glance to marriage history it is demonstrated that only people who married in a natural manner and formed a family are successful.

\subsection{Children's Health And Safety in Innate Marriage}

In verse 31 of Osara surah it is stated: "Do not kill your children by fear of poverty. We feed them so killing them is a huge mistake". In this Holy verse, if God addresses the actual parents in order to not to kill their children because of poverty then it is expected to say that $\mathrm{O}$ Thou women and men do not drag innocent children to wretchedness through perversion. One phenomenon that deprives children from their natural and spiritual needs is homosexual marriage and tendency. There is no doubt that children need nurturing and rearing. They also need constant and stable supervision provided only by their parents because only parents have this ability to raise and rear their children in an appropriate manner. When a woman is pregnant, she thinks about the years ahead of her, the way that she wants to take care of her child and the way that she wants to devote her life in order to guarantee her child happiness. These behaviors are considered as devotion in Islamic ethics. An Obliged and religious father also brings up this thought in his mind with his special way and by making it feasible tries to escort his wife in their child's perfection.

Now we ask: how is it possible to expect such devotion in homosexuals? Regarding this matter, a researcher has stated that, a homosexual house is not a safe place for children and since these homosexuals were previously perverted, how can we make sure that the children's safety is ensured in these houses and that they are protected from any sexual abuse (Finnis, 1994). Anthony Falzarano, the founder and ex-director of PFOX asserts: "almost 75 percent of homosexuals have molested children" (Transcript of an interview with Anthony Falzarano, Washington D.C., Ft. Lauderdale, 1998). An author has once stated: "We live in a world that family structure is altering expansively and deeply". There is no significant difference among rich and poor countries regarding this matter. Family as a constant and firm institution is losing its concept. It has been for multiple years that psychologists warn the influence of marriage failure, pregnancy especially teenage pregnancy, domestic quarrels, and other social abnormal lies. However, these warnings have not changed and were totally vain. Nowadays, most of us are collecting bitter and valueless products. All of this confusion has prepared the reason to refer to God's commands and to review the main purpose of God regarding the creation of men and women (Nicolosi, 1993).

\subsection{Homosexual Marriage and Humiliation of Marriage and Family Values}

"When you say that marriage is not exactly alliance between a man and a woman, this assertion can encompass other things like social norms, disciplines, and lifestyles. It was proven that unnatural and extrinsic marriage dilutes natural marriage" (Transcript from an interview with Genevieve wood, 2004). A person named Stanley Kurtz works in Hoover institution. He says, "Scandinavia is in the agony of death because homosexual marriage is common there". He continues that statistical expert's data and demographist's information indicates that a huge number of children are born out of matrimony in Sweden and Norway also $60 \%$ of children are the result of illegal relationships. In Norway liberal society where homosexuality idea is accepted in an expansive manner and registered officially, marriage is in the threshold of destruction.

\subsection{Extrinsic Marriage and Legal and Lawful System Challenge}

In Holy books, marriage is mentioned as a tremendous covenant or promise which is indicator of importance and massiveness of marriage. Just as God in prophetic mission took a condensed promise from his prophets this indicates the importance of innate marriage. A jurist named Craig Parshall has stated that, the Supreme Court of Massachusetts has created a nightmare in form of law, what they say is not only legal or civil essence but also it creates an order or ethical law to follow homosexuals and accept their marriage as an ethical and moral action. Now, the disgusting thing is the fact that Massachusetts has defined this law, if they continue to know homosexual marriage official actually a legal and basic crisis will generate for other states. This problem is as serious as the crisis of growth of plants' weeds. 


\subsection{Unnatural Marriage and Challenging Culture, Civilization, and Its Revolution from Civilization to Savagery}

Now, some people resign themselves to unnatural relationship in form of homosexual marriage actually by ignoring Gods' commands. It is proven throughout history that there is no society which can live with corruption devastation and remains dynamic and lively. These factors require a good manner and virtue. Prescription of decay in society affects family institution in a direct manner. In Craig Parshall assertion, one of jurists in family affairs siad: approval of immortality and corruption is an effective step in creating decadence in any society by which it moves from civilization and humanity point toward savagery. Anytime that a society has tried to dismantle ethics and humanity nothing has happened except devastation and decadence of society (Kennedy et al., 2004). In Islamic instruction, we have seen the truth in an efficient manner and considered various aspects of this affair which said corruption in a society as the result of compulsory downfall. In verse 85 of Araf surah it is mentioned: "We sent Jethro to Medina people. He said to his tribe, O Thou kin pray only begotten God who has no peer. Reasons and proofs are given to you people. Do not establish corruption after its reformation. This order is better if you have believed in it". Some interpreters have stated that Jethro invited people to this definition that they do not create decadence on earth and do not act against human nature which constantly invites human to reform world and arrange life affair" (Gardner, 2008). In verse 95 of Araaf surah he says: "If people of these cities have faith and were abstemiousness, we opened blessing from sky and earth for them but they neglected our commands and we reprimanded them for their actions". The author of Al-Mizan interpretation knows the real cause of extinction and deviation of the societies including debauchery and violation of the covenant. In commentary of the above verse, He says: "these societies are destroyed because most of their people were libertine and out of obedience" (Ibid).

\subsection{Unnatural Marriage and Society's Instability}

A stable society is indebted to resistance and permanence of marriage and family institution. If these two institutions are successful and stable, the society will be successful because its infrastructure is family. In Abrahamic religions, the principles, objectives, rights, and duties of marriage have been defined for both men and women to be used in their relationships and interactions with their children. Instability and mistakes are caused by aberration, ignorance and deviation of individuals. A person who follows the social norms will be successful in his/her life. People, who violate these rules and choose ways that are not defined in a clear manner, will become confused in their lives and encounter with lots of problems. Natural form of marriage is a bright way with a particular purpose. It aims at guiding men and women toward salvation. Tranquility and quietude in family is parallel to calmness in the society because God says: "this is God who created you from one body". This peace and stability will not form until under shadow of map (guidance) which is delineated in religion.

\subsection{Unnatural Marriage and Formality of Other Social Pervasions}

When a legal door opens to a deviation and abortion then all effects which are related to it should be licensed. Formalizing and legalizing homosexual marriage and other forms of marriage which are in contrast with natural and marriage can result in illegal phenomena including adultery, equality of illegitimate children with legitimate one, abortion and adoption of a child by lesbians or gays. This is Pandora's famous box which with opening its door all misfortunes will come true. Will Durant claims: "Epimetheus had a mysterious box which Promethee deposited to him and inhibited him from opening it. Pandora became curious when he saw this box so he opened it. Suddenly 10 thousand malevolencies came out of it and flied to make life hard for human" (Roshan, 2013). This Greek myth proves the reality of modern homosexual individuals who consider this form of marriage as a natural event. It is similar to the time that the box was opened and corruption and deviation developed and lead to devastation of marriage. A researcher has once said: "We tried to solve various problems caused by corruption and deviation but we can't understand what is wrong with this people that marry their dogs and even consult with their physicians about the possible risks of having relationships with these animals and ask them to do some experiments to be sure that their marriage will not generate any specific problem and that their animals are not ill" (Kennedy, 2004). One of the verses of Quran has emphasized on this fact: "so with this disposition where do you want to go?" This question reprimands those who violate the mentioned norms. Now, despite of the fact that the main objectives of marriage and its role in guiding people and societies toward salvation have been identified in the Holy books, some people still insist on violating these norms and neglecting the principles of natural marriage and family foundation.

\subsection{Unnatural Marriage, Decadence of Reproduction and Heckling in Children's Right}

We know that sterility and infertility for men and women is a concerning issue. The importance of reproduction is up to the point that some prophets pray God to give them children and he presaged them by granting their prayers. In first verses of Maryam surah, God commemorates his mercy for his bondman Zachariah, where he 
said to God: "Oh dear God, my bones (muscles) have become powerless and I have a head full of honey due to ageing. I never stopped saying my prayers. I am afraid of my heirs after I dye because my wife is infertile. Please give me a child by your side to inherit from me and the family of Jacob. Oh God! Make him praiseworthy. O Thou Zachariah, we presage you a son whose name is John and consider that this name hasn't been used before" (Maryam Surah, 2-7). Considering Quran verses it is obvious that children are gifts from the Almighty God but there is no reason that God presages his prophet to a child. People often give good news to each other. The first effect of homosexuality is being deprived of such magnificent blessings because essential term for giving birth to a child requires the presence of two individuals from opposite sex. Considering this fact, there is no reproduction in homosexual marriage which is equal to infertility. Homosexual individuals think that they can encounter with the above-mentioned problems using legal solutions including buying Sperm and ovum also implanting it in a hired uterus or placing zygote in fertility equipment. Whereas this behavior is against human nature and in opposition of natural trend, it cannot be substituted for natural reproduction. The love and kindness that mother feels toward her child in embryonic period since progeny coagulation until childbirth can never be the same in a lesbian because a lesbian mother is in the same situation. Finnis, an author has once said: "Considering the philosophical aspect of life and the general understanding of people regarding the lack of having enough abilities and talents in sexual relationships of homosexuals, it can be said that the unity and integrity of reproductive organs of husbands and wives increase their biological consistency. In fact, reproduction is a duty and function in which both women and men play an important role (Finnis, 1994).These two mentioned characteristics are part of marriage integrity which can be perceived only among husbands and wives. Dr. Kyle Pruett's assertions from Yale medical science and child's studies center are interesting: "biological parents have a considerable obligation and liability toward nurturing their children. However, considering the nature of nurturing in homosexual families, the presence of one of the parents is not necessary. Basically they cannot act as natural parents and they almost have only a limited amount of information about other gender" (Evan Gerstmann, 2004).

Western philosophers and thinkers are concerned about the risk of family foundation's destruction. They believe that this possible risk may begin as a result of family crises and deviation. Some family researchers believe that homosexual marriage often lasts for about 6 months to 1 year while during this period most of homosexuals especially guys are in relationship with 8 other male partners so children who are adopted by them can encounter with different problems especially mental disorders. They normally abandon these children because of their unusual situation (Amy Fagan, 2003). The author of war against family has stated: Despite of the fact that homosexuals encompass 1 to $4 \%$ of total population, studies show that they are in charge of $1 / 3$ to half of sexual harassments against children" (Gardner, 2008). The most important thing is that basically power of each society depends on having healthy and strong citizens. Different states require sufficient human forces in order to defend their territorial integrity against the potential aggression of the enemies, preservation of stability, internal and external tenacity, and development of country in different fields including political, economic, cultural, social, martial, and scientific dimensions. In other words, the human force of a society refers to the new born individuals of that society that will become adults and responsible for their own families in the future. Napoléon Bonaparte, the French governor says: "We need good mothers and women to rear children in an efficient manner because these children play an important role in the process of developing and promoting the current condition of France" (Dorant, 1986). Some family researchers explicitly informed from Muslims getting prepared to conquer the world by means of a successful family in rays of natural marriage and reproduction. They also say: "homosexuality is destructive for the society because it prevents marriage and reproduction. West is disintegrating now because the level of reproduction has been reduced in a remarkable manner. In fact these changes are the result of increasing the number of homosexual individuals". In contrast with Western societies in which every family has only one or two kids, Muslims have almost 10 to 12 kids. This method helps population growth and development. In fact, Muslim societies have a particular purpose from reproduction and it is sovereignty throughout the world. They practice this goal in their bedrooms and are winning. We do not want to intrigue a fight but we shouldn't forget that Muslims are waiting for overcoming us and becoming winners regarding this matter" (Kennedy et al, 2004). Considering the abovementioned statements, it can be said that both marriage and family affect the salvation and degree of success of different individuals and societies.

\section{Conclusion}

Using the rule that everything is recognized by its opposite and comparing natural and unnatural forms of marriage, it can be concluded that none of the abnormal and unusual forms of marriage can be substituted for natural relationships and marriage. In fact, any other form of sexual relationship violates the nature of human beings and so is not accepted because it forms new and inevitable crises for families. On the other hand since family is considered as the smallest and the oldest social unit, it is necessary to rear children in an efficient 
manner and based on ethics to guarantee their salvation. Considering this fact, it is not possible to reach tranquility in a society that religious commitments and ethics are neglected so there is no doubt that unnatural marriage is one of the destructive factors that bring nothing except deviation from humanitarian principles.

\section{References}

Christoph A, J. (2014). God \& Marriage. Plough publish house, Walden, New York.

Durant, W., \& Durant, A. (1986). The story of civilization. cultural and scientific press, No.11, Tehran.

Finnis, J. M. (1994). Law, morality, and sexual orientation, Notre Dame Law, quoted from Evan GER. same-sex marriage and the constitution, 1049-1076.

Gardner, W. (2008). Fight against families. Mohammadi, M. women studies and research office, Qom.

Kennedy, D. J., \& Newcomb, J. (2004). What is wrong with homosexual marriage? Crossway Books, The United States of America.

Nicolosi, J. (1993). Reparative therapy of male homosexuality, a cross-cultural perspective. NARTH Bulletin, No.4.

Rice, G., Anderson, C., Risch, N., \& Ebers, G. (1999). Male Homosexuality. Absence of linkage to microsatellite markers at xq28, Science, 284-665. http://dx.doi.org/10.1126/science.284.5414.665

Roshan, M. (2013). Family's right. Jungle press, Tehran.

Tabatabaee, M. H. (1988). Al-Mizan interpretation translation. Islamic publication office, No.17, Qom.

\section{Copyrights}

Copyright for this article is retained by the author(s), with first publication rights granted to the journal.

This is an open-access article distributed under the terms and conditions of the Creative Commons Attribution license (http://creativecommons.org/licenses/by/4.0/). 